Yeniçırak, H. (2021). Identifying dimensions of revolutionary change and transformation: a reference framework for studies on revolutionary movements. Uludağ University Faculty of Arts and Sciences Journal of Social Sciences, 22(41), 1151-1177.

DOI: 10.21550/sosbilder.873524

Research Article

\title{
IDENTIFYING DIMENSIONS OF REVOLUTIONARY CHANGE AND TRANSFORMATION: A REFERENCE FRAMEWORK FOR STUDIES ON REVOLUTIONARY MOVEMENTS
}

\author{
Hasan YENIÇIRAK*
}

Sending Date / Gönderim Tarihi: 2 February / Şubat 2021

Acceptance Date / Kabul Tarihi: 16 April / Nisan 2021

\begin{abstract}
There are revolution theories that formulate why and how the revolution occurred, which has a deep-rooted tradition of thought. Each attempt to theorize the revolution has some fundamental problems. No revolution theory covers all variables, but it is possible to reach some objective revolutionary criteria that try to understand and explain revolutionary change and transformation. In this work, we will examine the revolution theories and arrive at objective revolutionary criteria that will guide our understanding of revolutionary change and transformation. In this direction, we will begin our work by examining the theories of revolution and revealing the basic premises at the center of each revolution theory. Next, we will consider the main problems of the revolution theories we have examined. Finally, we will reveal the dimensions of revolutionary change and transformation that we can see in many revolutions, based on the revolution theories we have examined.
\end{abstract}

Key words: revolution, the natural history of revolution, psychological approach to revolution, systemic approach to revolution, structural approach to revolution

\footnotetext{
Dr., Siirt University Faculty of Arts and Sciences Department of Sociology, Siirt / TÜRKIYE, hasann.yenicirak@gmail.com
}

Uludağ Üniversitesi Fen-Edebiyat Fakültesi Sosyal Bilimler Dergisi Uludağ University Faculty of Arts and Sciences Journal of Social Sciences

Cilt: 22 Sayı: 41 / Volume: 22 Issue: 41 


\section{Devrimci Değişimin ve Dönüşümün Boyutlarını Belirleme: Devrim Hareketleri Üzerine Çalışmalar İçin Bir Referans Çerçevesi}

\section{ÖZET}

Köklü bir düşünce geleneğine sahip olan devrimin niçin meydana geldiğini, nasıl ortaya çıktı̆̆ını formülleştirmeye çalışan pek çok devrim teorileri vardır. Devrimi her bir teorileştirme çabası ise bazı temel problemlere sahiptir. Bütün değişkenleri içine alan bir devrim teorisi söz konusu değildir, ancak bu devrim teorilerinden hareketle devrimci değişimi ve dönüşümü anlamaya ve açılamaya çalışan nesnel birtakım devrimci ölçütlere ulaşılabilir. Bu çalışmada biz de devrim teorilerinin bir incelemesini gerçekleştirip, devrimci değişimi ve dönüşümü anlamamızda kılavuz rolü oynayacak nesnel devrimci ölçütlere ulaşmaya çalışacağız. Bu doğrultuda, ilk olarak devrim teorilerini incelemekle başlayacăğı. Devrim teorilerini inceleyip her bir devrim teorisinin merkezinde yer alan temel öncülleri açığa çıkarmaya çalışacağız. Ardından, incelediğimiz devrim teorilerinin temel problemlerini ele alacağız. Son olarak, incelediğimiz devrim teorilerinden hareketle, pek çok devrimde görebileceğimiz devrimci değişimin ve dönüşümün boyutlarını açı̆̆a çıkarmaya çalışacağız.

Anahtar kelimeler: devrim, doğal devrim tarihi, devrime psikolojik yaklaşım, devrime sistemik yaklaşım, devrime yapısalcı yaklaşım

\section{Introduction}

The idea of revolution is perhaps one of the most rooted and controversial concepts in thought history (Yeniçırak, 2020). When we look at the studies on revolution, we see that the idea of revolution has a deep-rooted tradition. Each revolution theorist raised different, essential questions about the underlying causes of the revolution. Based on these questions, they tried to theorize the revolution to understand and explain what the revolution is, what its components are, how it emerged, and what it aims.

Efforts to theorize the revolution are of paramount importance as they map the revolution's theoretical field. Each revolution theory 
tries to present us the dimensions of revolutionary change and transformation, which play a significant guiding role in understanding revolutionary change and transformation. However, before moving on to the theories of revolution, we need to answer a question: What will be our criterion when classifying revolution theories? Because, when we look at the readings on revolution, we see many classifications of revolution theories. For example, taking revolution from a sociological perspective, Charles Tilly presented a classification of revolution theory focusing on ideal types in a Weberian style. In this direction, Tilly created four interrelated categories that characterize the revolution theories: Marxian, Durkheimian, Millian, and Weberian. According to Tilly, Marx, Durkheim, Mill, and Weber have distinctively different views of the world and bequeathed to their heirs significantly further collective action analysis (Tilly, 1978). After giving these four categories, Tilly presents his theory: doggedly anti-Durkheimian, resolutely pro-Marxian, but sometimes indulgent to Weber and occasionally reliant on Mill (Tilly, 1978: 48). Roderick Aya divided the revolution theories into three categories: theories focusing on the intentions of the revolutionists themselves, theories taking into account the results of the revolutionary process, and theories focusing on the concept of multiple sovereignty (Aya, 1990: 14). This list can be extended further.

We will benefit from Goldstone and Foran's "the generational classification" while classifying the revolution theories. The generational classification, developed by Goldstone and continued by Foran, seeks to understand and explain the causes and origins of the revolution by focusing mostly on three "generations" of theories and theorists. According to this generational classification, the first generation of revolution is "the natural history of revolution". In particular, Brinton and Edwards have done significant work on "the natural history of revolution". The general theories of revolution follow 
the first generation. The second generation of theories are divided into two. First, the systemic approach to the study of revolution is revealed in Huntington and Johnson's work. Second, the psychological approach to the study of revolution is revealed in Gurr and Davies's work. The third-generation of revolution follows the second generation. Under the umbrella of "structuralism", the third-generation category of revolution systematically examines the causes of the revolutionary phenomenon. Compared to the first two, third-generation revolution theories offer a more homogeneous and consistent body of revolution.

We think that such a classification is much more useful in understanding revolution and revealing revolutionary change and transformation dimensions. Therefore, we will now first examine the theories of revolution according to this classification and demonstrate their fundamental propositions. Then, we will touch upon the basic problematics that emerge in each revolution theory. We will conclude our work by determining the dimensions of revolutionary change and transformation that we can see in many revolutions, based on the revolution theories we have examined.

Our chief purpose is to present the outlines of a systematic theoretical framework. We make no special claims for originality. All of the single components of this framework may be found in one place or another in the existing literature. However, very few attempts have previously been made to bring these diverse notions together into an integrated scheme.

\section{Theorizing Revolutions}

Every revolutionary theorist who tries to theorize the revolution takes different variables at the center of his/her work and tries to understand and explain revolutionary change and transformation based on these variables. Let us now briefly mention these revolution theories that try to understand and explain revolutionary change and 
transformation and their basic premises. Thus, we try to reveal the dimensions of revolutionary change to some extent.

\subsection{The Natural History of Revolution}

The first systematic study that tries to understand and explain revolution is the "The Natural History of Revolution". Edwards's "The Natural History of Revolution" and Crane Brinton's "The Anatomy of Revolution" are the building blocks of this revolution theory. "The Natural History of Revolution", which developed in the 1920s and 1930s, tries to identify a series of common features of the revolution, based on the British, American, French, and Russian revolutions. We will not explain all the observations of "The Natural History of Revolution". The main point we want to emphasize here is that some of Edwards and Brinton's observations on revolution are seen as law-like generalizations that we can observe in almost all revolutions. We will draw attention to these few points.

Edwards and Brinton's important observation of revolutionary action is that they both liken revolution to fire in the body. By associating revolution to fire in the body, Brinton says that revolution is an answer to institutions' dysfunction in society. What happened with the revolution is the abolition of these sick institutions (Brinton, 1952: 16-20).

Edwards and Brinton's more important observation of revolutionary action is on the advanced symptoms of the revolution. Stating the minor symptoms of the revolution, Edwards notes that these small symptoms will not necessarily follow the revolution, and then talk about the advanced symptoms necessary for the revolution. The first of these is the change of the intellectual elite. The defection of intellectuals constitutes one of the most important dimensions of revolutionary change and transformation (Brinton, 1952: 46). Another dimension of revolutionary change and transformation is the change of social myths 
and values (Edwards, 1970: 90-91). These three points revealed by Brinton and Edwards, namely, institutional change, the defection of intellectuals, and the change of social myths and values, constitute revolutionary change dimensions.

\subsection{The Systemic Approach to Revolution}

A more significant contribution to understanding revolutionary change comes from the systemic approach to revolution. While the theorists of the Natural History of Revolution focus their full attention on the revolutionary event sequence, those who approach the revolution systemically see revolution as the collapse of the social system in equilibrium (Goldstone, 1994: 5). We can point to Chalmers Johnson and Samuel Huntington as essential figures of systemic approaches to revolution.

Johnson's theoretical works on revolutions, Revolution and the Social System and Revolutionary Change, develop the systems model of revolution at the disequilibria social system level. According to Johnson, when synchronizing a society's environment and its values disappear, a revolutionary situation arises. Based on this idea, Johnson says that revolutions should be studied within the context of the social systems from which they emerge (Johnson, 1964: 1-22). Johnson even goes a little further and says that "the sociology of functional societies comes logically before the sociology of revolution" (Johnson, 1966: 3). According to Johnson, to understand how a society faces the threat of revolution, it is necessary to understand how societies function before determining which factors are responsible for society's dysfunction.

Huntington approaches the revolution in terms of modernization and argues that modernization both provides stability and causes instability. Modernization is a destabilizing process that generates tensions in political institutions. The main problem of politics is that the development of political institutions lags behind social and economic 
development. "The rates of social mobilization and the expansion of political participation are high; the rates of political organization and institutionalization are low. The result is political instability and disorder" (Huntington, 1968: 5). The process of modernization, which creates a gap between mobilization and the capacity of existing political institutions to meet new demands, creates the revolutionary situation. Revolution does not occur in societies without where this gap is absent. In other words, revolution does not occur societies where the level of social and economic complexity is very low, in traditional societies and in fully modernized societies. Revolution often occurs where the process of political development and political modernization lags behind the process of social and economic change.

\subsection{The Psychological Approach to Revolution}

Another approach to understanding and explaining revolutionary change and transformation is the psychological perspective. "The Natural History of Revolution" and "The Systemic Approach to Revolution" that we mentioned before focused on social factors. These two approaches evaluated society as entirely rational and overlooked the irrational dimension of society. However, as Le Bon stated, one of the pioneers of the psychological approach to revolution, collective action itself is somewhat unreasonable (Le Bon, 1913). In the collective action, the intellectual aptitudes of the individuals, and in consequence their individuality are weakened, unconscious qualities obtain the upper hand (Le Bon, 2002: 6) Mousnier clearly states the importance of the psychological approach in the following paragraph:

There is no strict determinism in the matter of revolt and revolution, no logical sequence, no direct link between the set of circumstances explaining and justifying revolt and the act of revolt itself. The link is a psychological one a very complex psychological one, and in the most cases, the historian is unable to enter into the 
psychology, conscious or subconscious, of the men he studies (Mousnier, 1970: 157-158)

Psychological explanation of revolution based on the individual and the individual's perception of the social situation. There are two psychological explanation of revolution: individual-centered and groupcentered approach. The individual-centered approach focuses on the personal characteristics of the leaders. This approach tries to explain how important the leader is to the revolutionary movement, how the leader directs the revolutionary movement, and how the leader determines the revolutionary policies. Wolfenstein, one of the pioneers of this approach, tries to arrive at a model of the psychological roots of revolutionary involvement and leadership that will be valid for a fairly wide range of cases. In this direction, "he tries to answer the following questions: why does a man become a revolutionist? What personal qualities will help him to be an effective leader of men?" (Wolfenstein, 1967: 2). To answer this question, this approach focuses on individuals' early life experiences (Erikson, 1977: 13-14, 364). As Lasswell states, certain types of personal experience lead to an inclination to perform certain political functions (Lasswell, 1986).

The group-centered approach tries to understand and explain how groups respond to circumstances. This approach is actually divided into three within itself: "the repression of instincts" pioneered by Pitirim Sorokin, "the theory of rising expectations" theorized by James C. Davies, and "the theory of relative deprivation" advocated by Robert Gurr.

According to Sorokin, the revolution's reason is the repression of certain instincts and the impossibility of realizing the instincts (Sorokin, 1925: 373-382). Sorokin's thinking is detailed in Davies's "the theory of rising expectations". According to this theory, those who carried out the revolution were not in disaster. According to Davies, 
"revolutions are most likely to occur when a prolonged period of objective economic and social development is followed by a short period of sharp reversal" (Davies, 1962: 6). When the gap between the expected satisfaction and the existing satisfaction becomes intolerable, the revolution will occur.

Davies' thinking was followed by Gurr's "the theory of relative deprivation". According to Gurr, "relative deprivation is defined as actor's perception of discrepancy between their value expectations and their value capabilities" (Gurr, 1970: 24). And Gurr goes: "... the necessary precondition for violent civil conflict is relative deprivation" (Gurr, 1968: 254). "The frustration-aggression hypothesis" lies at the center of this explanation model, which includes all three. It is a model that sees human aggression as the result of disappointments. Revolutions are the product of people and groups whose expectations have not been realized.

\subsection{The Structural Approach to Revolution}

Based on the structural characteristics of the social order, structural revolution theories mainly focus on classes, states, inter-state struggle, and international economic systems. There is the Marxist idea of revolution in the background of the structural revolution theories. As M. L. Fein said, "Marx is the ideological father of structural revolution theories" (Fein, 2015: 65). Within the Marxist tradition of thought, all revolutionary changes appear as a structural change. Accordingly, the most important reason for revolutionary change is the structural arrangements of society (Cohan, 1975: 56).

One of the most important factors that can provide this structural change is the nation-state. As Kimmel showed, "many scientists are today focusing on the state as a central variable in the revolutionary equation" (Kimmel, 1990: 145). There are four types of state-centered analysis. Jeff Goodwin expresses these four types as follows: "the state- 
autonomy", state-capacity, political opportunity, and stateconstructionist approaches" (Goodwin, 1997: 10).

The state is critical to understand and explain revolutionary change and transformation. According to Marx, the importance of the state in understanding revolutionary change and transformation can be understood with reference to class struggles. The class forms the basis of Marxist analysis. Each revolution is the work of a particular class. As writes Tucker, "if revolutions are the locomotives of history, class struggles are the locomotives of revolution" (Kimmel, 1990: 19). The state is the instrument of the pressure exerted by one class on the other.

But the revolution needs to be considered not only in the context of class struggles within the state, but also in the international and world-historical context (Skocpol, 1979: 39). Revolutions occur in backward states faced with a crisis emerged economic and military competition with stronger states in the developed international economic and political system.

Revolutionary change and transformation cannot be understood with reference to the internal dynamics of any particular nation. International market competition is also very effective in the emergence of revolutionary attempts. Wallerstein draws attention to this point. Wallerstein tries to make a sociological explanation of the revolution with the idea of the world system. According to Wallerstein world system is a unit of social change analysis. Wallerstein makes a strong case that revolution must be seen as the political response by economic actors, mobilized by their activities within the world system (Kimmel, 1990: 99). When we evaluate it in terms of the structural analysis of the revolution, we can briefly say that the international economic dimension plays a vital role in the analysis of revolution, but it is not the only decisive role. Class relations and the state's role also play an equally vital role in explaining any revolutionary event. 


\section{Limits of Theoretical Approaches to Revolution}

All of the efforts to theorize the revolution we briefly examined above are very important as they map the revolutions' theoretical field. Each approach plays a significant guiding role in understanding and explaining revolutionary change and transformation, but it has some fundamental problems. Now, we try to state what these fundamental problems are briefly.

The most significant criticism of the Natural History of the Revolution comes from Goldstone and Foran. Goldstone said that "the legacy of the natural historians of revolution provided a valuable guide to the process of revolution, but the basic question remained unanswered such as "why did revolutions arise?" (Goldstone, 1994: 4). Like Goldstone, Foran made a similar criticism. Foran said that "the critique commonly aimed at pioneers of theory is that they merely describe the process of revolution, they do not explain why revolutions occur" (Foran, 2005: 9).

The most important problem of the psychological approach to revolution is that it has some uncertainty in explaining where and how revolutions occurred. As Cohan said, the psychological approach cannot determine an intolerable gap between expected and actual need satisfaction. It makes an effort to explain that the wider the gap, the more violent and widespread the revolution is likely to be, but it does not say anything about why some societies can tolerate a vast gap and others cannot (Cohan, 1975: 199). Goldstone makes similar criticisms to the psychological approach. Although the idea that "the repression of instinct, relative deprivation breeds revolutions" in the psychological approach is correct to some extent, the psychological approach does not explain why revolutions occur in some countries and not in others. In addition to this, "the repression of instinct" and "relative deprivation" 
are widespread throughout history; revolutions are rare (Goldstone, 1994: 1-2).

The most comprehensive critique of the systemic approach to revolution comes from John Foran. Foran draws attention to observing and measuring societal disequilibrium, which is the fundamental problem of the systemic approach to revolution. This approach has some difficulties in explaining where and how revolutions occur. As Davies himself remarked of Chalmers Johnson: "If one tells an automobile mechanic that the car's engine is dysfunctional, it is just about as clear and true as when one says it about an old society" (Foran, 2005: 9). Goldstone points out another problem of the systemic approach. As Goldstone said, although revolutionary theorists debated modernization caused revolutions by creating an imbalance in society, modernization theory has changed drastically (Goldstone, 1994: 6). This paved the way for the structural revolution theories.

Structural revolution theories try to correct the lack of nonstructural revolution theories by mainly focusing on classes, states, inter-state struggle, and international economic systems. But structural revolution theories, like other revolution theories, also face some fundamental problems. The first of these is about human agency. As Kimmel pointed out, "many structural theorists leave out human beings altogether to avoid psychologizing revolution, but human agency is essential to the phenomenon of revolution, and sociological analysis that fails to take into account the experiences and motives of the actors themselves" (Kimmel, 1990: 188-189). People may not shape the revolution the way they want, but they make it happen. The second, and more importantly, is about culture and ideology. While structural theorists focus on the relationship between classes, autonomous states, and the broader international system, they mostly neglect the importance of culture and ideology. This is exactly why Goldstone and Foran sought to reveal the importance of culture and ideology in 
understanding revolutionary change and transformation (Goldstone, 2001: 154-157) According to Foran, the social structure has to be assessed from various angles that promise fresh insight; for example, the whole domain of culture must be explored more deeply (Foran, 1993: 16).

All this shows us that it is impossible to talk about a theory of revolution that includes all variables. However, as Tilly points out, it is still possible to show that similar causal mechanisms play a role in revolutionary situations that constitute a wide spectrum (Tilly, 1995: 89).

\section{Dimensions of Revolutionary Change and Transformation}

What are some similar causations that we can see in many revolutions? In other words, what are the dimensions of revolutionary change and transformation? Now, departing from the revolutionary theories explained above, we try to reveal the objective variables that occur in the event of revolution.

We will draw attention to the four dimensions of revolutionary change and transformation that we can see in many revolutions. These are as follows: the transfer of the allegiance of the intellectual, the institutional change, the structural change, and the change of social myths and values. This is somewhat similar to Cohan's classification but differs significantly from it. For example, Cohan also mentions violence and legitimacy as dimensions of revolutionary change and transformation. But violence and legitimacy are not a necessary feature of the revolution.

Some theorists of revolution do not accept the idea that revolution necessarily entails violent action. When we look at reflections on revolution, some revolutionary theorists say that violence is a necessary part of the revolution, while some revolutionary theorists 
say that violence is not an essential part of revolution. For example, While Gurr and Davies, who psychologically approach the revolution, see violence as a necessary part of the revolution, Tilly states that violence is not an essential part of the revolution. In From Mobilization to Revolution, Tilly wrote that

"It does not predict clearly to the curve of violence before a revolution, since that depends on the pattern of mobilization and contention leading to the establishment of multiple sovereignty. Yet it does deny the necessity of a buildup of violence before a revolution." (Tilly, 1978: 217)

In addition to violence, popular involvement also is not the necessary characteristics of revolution. Studying the required characteristics of revolution, Kotowski, in his work Revolution, mentions popular involvement as one of the required characteristics of revolution (Kotowski, 1984: 414-416). But we may not see popular involvement in all revolutionary changes. As Kotowski points out, Gurr and Davies speak of this popular involvement when describing how revolutionary discontent was created. They even build almost all of their work on it. But, this is not what all revolutionary thinkers assert. Going back to Tilly, popular involvement is not a necessary feature of the revolution, as Tilly's concept of revolution requires only the unconstitutional transfer of power.

This list can be extended. However, this is not the purpose of our study. Therefore, we turn again to the four dimensions of revolutionary change and transformation that we can see in many revolutions and explain each dimension.

\subsection{The Transfer of the Allegiance of the Intellectual}

One of the most critical dimensions of revolutionary change and transformation is the transfer of the allegiance of the intellectual. Indeed, Lasswell defines revolution as the change in the formation of 
the elite (Cohan, 1975: 22). Taking revolution in this way, Laswell clearly emphasizes how important the transfer of the allegiance of the intellectual is in revolutionary change and transformation (Lasswell, 1936).

For example, the transfer of the allegiance of the intellectual was one of the most important reasons for the emergence of the revolution in France in 1789. According to Aulard, the philosophers who formed the intellectual foundations of the revolution were not opposed to the king in the early days. They did not use the word Republic (Aulard, 2011: 10-16). However, these intellectuals, who did not demand the Republic at first, later laid the groundwork for forming the idea of the Republic and established the intellectual foundations of the revolution. While Voltaire attacks the past, tradition and the institutions that maintain order, which is the first goal of the revolution (Voltaire, 1965: 37-39), Condorcet tries to create the new human, the new society, which is the second goal of the revolution (Condorcet, 1996: 27).Therefore, the transfer of the allegiance of the intellectual constitutes one of the essential dimensions of revolutionary change and transformation.

"The Natural History of Revolution" and functionalists who have attempted to theorize revolutionary change and transformation draw particular attention to the transfer of the allegiance of the intellectual. Edwards, one of the founders of "The Natural History of Revolution," and Johnson, who approaches revolution as a systemic, asserted that the transfer of the allegiance of the intellectual is among the most important dimensions of revolutionary change and transformation. More importantly, both Edwards and Johnson say that the transfer of the allegiance of the intellectual occurs in almost all revolutionary changes and transformations. 
The change of the elite is one of the essential parts of Johnson's revolution model. In Revolution and Social System, Johnson explains how important elite conflict is in a revolutionary change in these words: "If the elite is not intransigent, simple change will occur, dysfunction will be relieved, and no revolution will take place" (Johnson, 1964: 7).

It is Edwards who best demonstrates the importance of elites and intellectuals' allegiance in the process of revolutionary change and transformation. In Natural History of Revolution, after enumerated the preliminary symptoms of a coming revolution, such as general restlessness, rising crime rates, Edwards points out that these preliminary symptoms do not mean that revolution necessarily follows. Later, Edwards states that two master symptoms are necessary for the revolution to occur. The first master-symptom of revolution is the "transfer of the allegiance of the intellectuals" (Edwards, 1970: 22-40). Academics, writers, editors, artists all play a significant role in society.

"The transfer of the allegiance of the intellectuals" heralds the revolutionary change and transformation because it prepares the ground for the change that will occur in the structure, values and institutions of the society. Again, to refer to Edwards's thoughts, intellectuals focus the dissatisfaction of the masses on the social structure and institutions and thus lay the groundwork for the change of social structure and institutions (Edwards, 1970: 46-51). This intellectuals' attitude, one of the most important characteristic signs of the revolution, continues to increase violently until the existing institutions and values lose all legitimacy. When we consider all this, we can clearly see that the transfer of the allegiance of the intellectuals constitutes one of the most important dimensions of revolutionary change and transformation.

\subsection{The Institutional Change}

The second point we need to mention when discussing the dimensions of revolutionary change and transformation is the 
institutional change. The whole revolutionary change process goes hand in hand with institutional change. Therefore, Johnson, Huntington, Edwards, and Brinton said that the institutional change is an essential feature in almost all revolutionary change. We see the results of the revolutionary transformation at the earliest in institutional change. Every revolution breaks down the privileged institutions of the order it wants to destroy and creates institutions that will build its order in its place (Cobban, 1999: 75).

It is somewhat difficult to distinguish institutional change from structural change, which we will talk about a little later, but we will treat institutional change as a change in political institutions (Cohan, 1975: 19). Accordingly, we will turn our face to Johnson again. In analyzing the change in political institutions caused by the revolution, Johnson talks about three levels of this change. Two of these are very important to us: change of government and regime change. According to Johnson;

"By "government", we mean the formal political and administrative institutions that make and execute decisions for the society - that is to say, the institutionalized expressions of the statuses of authority. Resorts to violence in order to cause changes at this level will be simple rebellions; they seek to replace persons who are believed to be occupying various authority positions illegitimately.

"Regime" refers to the fundamental rules of the political game in society: democracy, dictatorship, monarchy, oligarchy, federalism, constitutionalism, and the like, are characteristics of different kinds of regimes." (Johnson, 1966: 140)

If we continue with the example of the French Revolution, the biggest institutional change in the French Revolution is the regime changes. French revolutionaries struggled to overthrow the monarchy and build a democratic republic in its place. Therefore, Sade said that 
"the French try a little more, destroy forever anything that could blow your work if you want to be a republic" (Sade, 2019: 154-155).

As Johnson put it, change in political institutions includes regime change and constitutional change, change of a legislature, or change of certain functions of the legislature. More importantly, we should not consider institutional change only in the political sphere. We can see the institutional change that occurs in all areas of society. Therefore, when examining the dimensions of revolutionary change and transformation from an institutional perspective, the point we will focus on will be all other social institutions such as economy, education, religion. The point that makes institutional change so important is that it reflects the change in the social structure.

\subsection{The Structural Change}

The change of social structure constitutes another dimension of revolutionary change and transformation. As we have stated above, it is difficult to separate structural change from institutional change because structural change also includes institutional change. However, structural change involves much more than institutional change. The structural change also refers to a change in society's general class relations, in addition to institutional change (Cohan, 1975: 19). In this sense, among all the revolution theories, none is more influential than the Marxian tradition of revolution. As mentioned above, at the center of the Marxist idea of revolution lies the idea that revolution is the change of social structure.

Every revolution creates its class. It tries to complete the revolutionary transformation through the class it creates. Continuing from the French Revolution, it wanted to realize its social project with the bourgeoisie. July 14, 1789, is the victory of the bourgeoisie; The Constituent Assembly is the legislative body of the bourgeoisie; The 
National Guard, which is the guardians of the revolution, is the armed forces of the bourgeoisie (Mignet, 1926: 65).

The revolution changes the general class relations of society by confiscating property. As Pitirim Sorokin states, who looks at the revolution from a psychological perspective, confiscation of property is one of the primary conditions of all revolutionary attempts (Sorokin, 1925: 29-30). The period of revolutionary change and transformation is, in a sense, the period of confiscation. Indeed, Burke also drew attention to this reality. As Edmund Burke states, "revolutions are favorable to confiscation" (Burke, 1951: 151).

The concept of property should not be considered alone. Property is also associated with social institutions and values. Property plays an essential role in shaping the values of social institutions. That is why the revolution that seeks to overthrow the existing social order tries to change the property structure. This situation, which we can see in many revolutions, was revealed in all its nakedness in the French Revolution of 1789. The French Revolution of 1789 first seized the Church's property to eliminate Catholic Christianity from the memory of society completely. The French Revolution of 1789 took away the material power of the Church by seizing the property of the Church. To better understand the rationale and necessity of revolutionary confiscation, let's listen to the priest of the revolution, TalleyrantPerigord: "when immense wealth has a traditional allocation contrary to new interest and the very life of the Nation, it can and must modify this allocation" (Jaures, 2015: 49).

\subsection{The Change of Social Myths and Values}

The change of social myths and values constitutes an essential dimension of revolutionary change and transformation. The three changes mentioned above, "The transfer of the allegiance of the 
intellectuals", "the institutional change" and "the structural change" reveal the "the change of social values and myths".

Revolutionary change is precisely that kind of social change which occurs when the basic values of social order are rejected and new values accepted. Moreover, in order to mobilize unrest and discontent and prepare for action, the people must be led to believe that they are on the march toward a New Order -a potential Utopia which it is their duty to help actualize (Hopper, 1950: 274). Social myths and values are created in revolution. Without the desire for this ideal, revolutionary troops could not survive. For example, the French Revolution had a social myth (Lefebvre, 2005). The social myth of the French Revolution is still to be seen epitomized in the three words engraved on the public buildings of France: Liberté, Egalité, Fraternité. Enthusiasm for the principles embodied in these words swept over France like a new religion (Edwards, 1970: 95). The French Revolution promised a new paradise. The French revolutionists were also apostles of a new faith. According to the Jacobins, this heaven was to be definitely here on earth. After the dictatorship of the revolutionary government, this heaven was to appear (Brinton, 1952: 250). Similarly, in 1917 Liebknecht cried "we are fighting for the gates of heaven" (Camus, 1991: 211).

Indeed, the revolution theories mentioned above, especially nonstructuralist theories, state that revolution is fundamentally a social value, a social myth change. Huntington, Sorokin, Neumann, and others who have attempted to theorize revolution have particularly emphasized this dimension of revolutionary change. Huntington defines revolution as follows, including revolutionary change and all dimensions of transformation: "A revolution is a rapid, fundamental, and violent domestic change in dominant values and myths of a society, in its political institutions, social structure, leadership, and government activity and policies" (Huntington, 1968: 264). Neumann uses a similar 
definition like Huntington. According to Neumann "The revolution is a sweeping, fundamental change in political organization, social structure, economic poverty control and the predominant myth of a social order..." (Neumann, 1949: 333). Sorokin goes a little further and says: Revolution is a change in the behavior, beliefs, and ideology of the people; ... in the biologic composition of population; ... in the social structure of society" (Sorokin, 1925: 11).

\section{Conclusion}

This study, in which we try to determine the dimensions of revolutionary change and transformation, has deficiencies in many aspects. The first shortcoming arises from the revolution theories we examined. While examining each theory of revolution, we tried to focus on a few points specifically. We have not provided a detailed account of all the premises of each theory of revolution, because such an attempt would lead to other inextricable problems. It is clear that each revolution theory we examine and try to determine its basic premises within the limits of our study is in scope and depth that can be the subject of more than one book. The second shortcoming arises in detailing the dimensions of the revolutionary change and transformation we have identified. We could examine and elaborate the dimensions of the revolutionary change and transformation we have identified, based on all revolutions. However, such an attempt would cause much greater problems. If this work is transformed into a book study and expanded, these two shortcomings mentioned above can be removed to a certain extent.

However, despite all these shortcomings, this study is significant in terms of presenting us the dimensions of revolutionary change and transformation. What we are trying to do here is not just a study of revolution theories. What we are trying to do here is to try to determine the dimensions of revolutionary change and transformation based on the 
revolution theories we examined. Accordingly, we have found out four revolutionary criteria that we can see in many revolutionary changes and transformations: The transfer of the allegiance of the intellectual, the institutional change, the structural change, and the change of social myths and values. These four revolutionary criteria give us an account of the extent to which any process of change and transformation is a revolutionary process of change and transformation. This study's most essential purpose is to provide a basis for us to consider the extent of the changes and transformations that occur today, based on the revolutionary change and transformation dimensions we have determined.

\section{Information Note}

The article has been prepared in accordance with research and publication ethics. This study does not require ethics committee approval.

\section{References}

Aulard, A. (2011). Fransa Inkılabının siyasi tarihi. (Trans: N. Poroy), I, Türk Tarih Kurumu Press.

Aya, R. (1990). Rethinking revolution and collective violence: studies on concept, theory and method. Het Spinhus.

Brinton, C. (1952). The anatomy of revolution. Vintage Books.

Burke, E. (1951). Reflections on the French Revolution. J. M. Dent \& Sons Limited.

Camus, A. (1991). The rebel: an essay on man in revolt. Vintage Books.

Cobban, A. (1999). The social interpretation of the French Revolution. Cambridge University Press. 
Cohan, A. S. (1975). Theories of revolution: an introduction. A Halsted Press Book.

Condorcet, M. (1996). İnsan zekasının ilerlemeleri üzerine tarihi bir tablo taslăğ II. (Trans: O. Peltek), Milli Eğitim Press.

Davies, J. C. (1962). Toward a Theory of revolution. American Sociological Review, 27(1), 5-19.

Edwards, L. P. (1970). The natural history of revolution. The University of Chicago Pres.

Erikson, E. H. (1977). Childhood and society. Paladin Grafton Books.

Fein, M. (2015). Evolution versus revolution. Transaction Publishers.

Foran, J. (1993). Theories of revolution revisited: toward a fourth generation? Sociological Theory, 11(1), 1-20.

Foran, J. (2005). Taking power: on the origins of third world revolutions. Cambridge University Press.

Goldstone, J. A. (1994). Revolutions: theoretical, comparative, and historical studies. Harcourt Brace \& Company.

Goldstone, J. A. (2001). Toward a fourth generation of revolutionary theory. Annual Review of Political Science, 4(1), 139-187.

Goodwin, J. (1997). State-centred approaches to social revolutions: strengths and limitations of a theoretical tradition. In J. Foran (Ed.), Theorizing Revolutions (pp. 9-35), Routledge.

Gurr, R. (1970). Why men rebel. Princeton University Press.

Gurr, T. (1968). Psychological factors in civil violence. World Politics, 20(2), 245-278. 
Hopper, R. D. (1950). The revolutionary process: a frame of reference for the study of revolutionary movements. Social Forces, 28(3), 270279.

Huntington, S. (1968). Political order in changing societies. Yale University Press.

Jaures, J. (2015). A socialist history of the French Revolution. Pluto Press.

Johnson, C. (1964). Revolution and social system. Hoover Institution Studies.

Johnson, C. (1966). Revolutionary change. Little, Brown and Company Inc.

Kimmel, M. S. (1990). Revolution: a sociological interpretation. Polity Press.

Kotowski, C. M. (1984). Revolution. G. Sartori (Ed.), In Social Science Concepts: A Systematic Analysis (pp. 403-451). Sage Publications.

Lasswell, H. D. (1936). Politics: Who gets what, when, how. McGraw Hall.

Lasswell, H. D. (1986). Psychopathology and politics. University of Chicago Press.

Le Bon, G. (2002). The crowd: a study of the popular mind. Dover Publications, INC.

Lefebvre, G. (2005). The French Revolution. (Trans: E. M. Evanson), Routledge.

Mignet, F. (1926). The history of the French Revolution. J. M. Dent \& Sons Limited. 
Mousnier, R. (1970). The Fronde. R. Forster, J. P. Greene (Eds.), In Preconditions of Revolution in Early Modern Europe. Johns Hopkins University Press.

Neumann, S. (1949). The international civil war. World Politics, 1(3), 333-350.

Sade, M. (2019). Yatak Odasinda Felsefe. (Trans: S. İ. Ortaer Montanari), İthaki.

Skocpol, T. (1979). States and social revolutions: a comparative analysis of France, Russia and China. Cambridge University Press.

Sorokin, P. A. (1925). The sociology of revolution. J. B. Lippincott.

Tilly, C. (1978). From mobilization to revolution. Random House.

Tilly, C. (1995). European revolutions, 1492-1992. Blackwell Publishers.

Voltaire. (1965). Felsefe sözlüğ̈̈ III. (Trans: L. Ay). Milli Eğitim Press.

Yeniçırak, H. (2020). On revolution: What is revolution? What are the differences that distinguish revolution from other forms of political violent? Van Yüzüncü Yıl University the Journal of Social Sciences Institute, (50), 329-342.

Uludağ Üniversitesi Fen-Edebiyat Fakültesi Sosyal Bilimler Dergisi Uludağ University Faculty of Arts and Sciences Journal of Social Sciences Cilt: 22 Sayı: 41/Volume: 22 Issue: 41 
Identifying Dimensions of Revolutionary Change and Transformation: A Reference Framework for Studies on Revolutionary Movements

\section{EXTENDED ABSTRACT}

The purpose of this study is to reveal the outlines of the theoretical framework of revolution. There are revolution theories that formulate why and how the revolution occurred. In this direction, we first examine the revolution theories. Accordingly, we mention four revolution theories:

- The natural history of revolution

- The systemic approach to revolution

- The psychological approach to revolution

- The structural approach to revolution

Each revolution theory we mentioned takes different variables into the center and tries to understand revolutionary change and transformation based on these variables. The Natural History of Revolution tries to identify a series of common features of the revolution, based on the British, American, French, and Russian revolutions. The systemic approach sees revolution as the collapse of the social system in equilibrium. The structural revolution theories mainly focus on classes, states, inter-state struggle, and international economic systems. The psychological approach examine revolution in terms of irrational dimension of society. Accordingly, collective action itself is somewhat unreasonable.

Each approach plays a significant guiding role in understanding and explaining revolutionary change and transformation, but it has some fundamental problems. While structural theorists focus on the relationship between classes, autonomous states, and the broader international system, they mostly neglect culture's importance. The systemic approach observes and measures social disequilibrium but does not explain where and how revolutions occur. In the same way, the psychological approach focuses on the irrational dimension of society, such as satisfaction, aggression, and frustration, but cannot explain why revolutions occur in some countries and not in others.

However, it is possible to reach some objective revolutionary criteria that try to understand and explain revolutionary change and transformation despite all these shortcomings. We draw attention to the four dimensions of revolutionary change and transformation that we can see in many revolutions. These are as follows:

- The transfer of the allegiance of the intellectual 
- The institutional change

- The structural change

- The change of social myths and values

The Natural History of Revolution and the systemic approach draw particular attention to the transfer of the allegiance of the intellectual. They assert that the transfer of the allegiance of the intellectual is among the most important dimensions of revolutionary change and transformation. They also said that institutional change is an essential feature in almost all revolutionary change. The structural approach draws especially attention to general class relations of society as the structural change. Lastly, the change of social myths and values constitutes the essential dimension of revolutionary change and transformation. Each revolution theory, especially non-structuralist theories, draws this point. They state that revolution is fundamentally a social value, a social myth change. To sum up, we have found out four revolutionary criteria that we can see in many revolutionary changes and transformations: The transfer of the allegiance of the intellectual, the institutional change, the structural change, and the change of social myths and values. These four revolutionary criteria give us an account of the extent to which any process of change and transformation is a revolutionary process of change and transformation. 